Int. J. Dev. Biol. 57: 211-219 (2013)

doi: $10.1387 / \mathrm{ijdb} .130028 \mathrm{pk}$

\title{
Nodal/Cripto signaling in fetal male germ cell development: implications for testicular germ cell tumors
}

\author{
CASSY M. SPILLER, JOSEPHINE BOWLES and PETER KOOPMAN* \\ Institute for Molecular Bioscience, The University of Queensland, Brisbane, Australia
}

\begin{abstract}
Testicular cancer is the most frequent cancer in young men aged 15-40 years and accounts for $1 \%$ of all cancer diagnosed in males. Testicular germ cell tumors (TGCT) encompass a broad group of cancers, each displaying different levels of pluripotency and differentiation as well as malignancy potential. The TGCT cell of origin is thought to be a fetal germ cell that failed to correctly differentiate during development: this is known as the 'fetal origins hypothesis'. This theory predicts that developmental pathways that control germ cell pluripotency or differentiation may be involved in the malignant transformation of these cells. Recently the Nodal/Cripto signaling pathway, known to control pluripotency and differentiation in embryonic stem (ES) cells, was implicated in regulating normal male fetal germ cell pluripotency. Although genes of this pathway are not normally expressed in germ cells during adult life, ectopic expression of this pathway was detected in several sub-groups of TGCTs. In this review, we consider the evidence for the fetal origins of TGCT and discuss the implications of Nodal/Cripto signaling in various aspects of germ cell development and cancer progression.
\end{abstract}

KEY WORDS: germ cell, nodal, cripto, testicular germ cell tumor

\section{Introduction}

During fetal development, primordial germ cells (PGCs) migrate to take up residence in the nascent gonads, and then respond to molecular cues from gonadal somatic cells that regulate their proliferation and sex-specific development. In a mouse fetal ovary, PGCs enter meiosis and commit to oogenesis, whereas in a fetal testis, they avoid entry into meiosis and instead undergo mitotic arrest and begin to differentiate towards spermatogenesis (Hilscher 1974; McLaren and Southee 1997). Recent studies have identified some of the key somatic factors involved in regulating fetal germ cell behavior appropriately (Barrios et al. 2010; Bowles et al. 2010; Bowles et al. 2006; Koubova et al. 2006).

It is currently hypothesized that dysregulation of PGC development can result in germ cell tumours. In mice, these can take the form of testicular teratomas that contain a wide range of differentiated cell types (Jiang and Nadeau 2001; Stevens 1967; Stevens 1984). Similarly, in humans, germ cells that are not controlled appropriately or that incompletely differentiate during fetal life has been linked to the development of testis cancer later in life. In the present review, we discuss the origins and characteristics of testicular cancer in more detail before focusing on the Nodal/
Cripto signaling pathway that has recently been implicated in fetal germ cell pluripotency and development of the tumorigenic state.

\section{Testicular germ cell tumors}

Testicular germ cell tumors (TGCTs) are the most common solid tumor of young men aged between 15 and 45 years (Adami et al. 1994). The lifetime risk of testis cancer is estimated at approximately $0.5-1 \%$; environmental and genetic factors, subfertility and abnormal testis development all contribute to susceptibility (Heimdal et al. 1997; Hemminki and Li 2004; Horwich et al. 2006). Various histological subtype of testis cancer are observed, and most occur in the testicles although some tumors also arise in extra-gonadal locations. The majority of TGCTs (more than 95\%) originate from the fetal germ cell population of the testis (Ulbright 1999).

\footnotetext{
Abbreviations used in this paper: $\mathrm{CH}$, choriocarcinoma; CIS, carcinoma in situ; EC, embryonal carcinoma; EG, embryonic germ; EpiSC, epiblast stem cell; ES, embryonic stem; FGF, fibroblast growth factor; GCT, germ cell tumor; GWAS, genome wide association study; NS, non-seminoma; PGC, primordial germ cell; SE, seminoma; TE, teratoma; TGCT, testicular germ cell tumor; TGF $\beta$, transforming growth factor beta; YST, yolk-sac tumor.
}

\footnotetext{
*Address correspondence to: Peter Koopman. Institute for Molecular Bioscience, The University of Queensland, Brisbane, QLD, 4072, Australia. Tel: +61-7-3346-2059. Fax: +61-7-3346-2101. e-mail: p.koopman@imb.uq.edu.au - web: www.imb.uq.edu.au/groups/koopman
}

Final, author-corrected PDF published online: 5 June 2013. 


\section{Subtypes of TCGTS}

Type ITGCTs (infantile germ cell tumors) arise from early PGCs and develop as teratomas and yolk-sac tumors (YST) in neonates and children. These tumors often arise at extra-gonadal locations such as the neck, midline brain and retroperitoneum, presumably because the transformation occurs as the PGCs are migrating towards the gonads during embryonic development (van de Geijn et al. 2009).

Type III germ cell tumors arise from differentiated spermatogonium/spermatocytes of the adult testis and develop as spermatocytic seminomas in elderly men. These tumors, along with Type I GCTs, are extremely rare and the incidence level has remained constant over several decades (Visfeldt et al. 1994).

Type IITGCTs arise from fetal gonadal germ cells, which, instead of differentiating into spermatogonia, develop as pre-invasive CIS (Skakkebaek 1972). TGCTs of Type II do not develop until after puberty and can be further divided into two sub-groups: seminomas (SE) and non-seminomas (NS), both of which display many markers of both fetal germ cells and pluripotency (Fig. 1) (Sonne et al. 2009; van de Geijn et al. 2009). Seminomas are characterised by germ cell-like gene expression and are the least-invasive Type II germ cell tumor. Conversely, non-seminomas comprise both highly pluripotent/undifferentiated pathologies (YST and embryonal carcinoma; EC) as well as differentiated pathologies containing cells from all three germ layers (choriocarcinoma; $\mathrm{CH}$, mixed NS and teratoma; TE). Approximately $10-15 \%$ of GCTs are mixed tumors, containing both SE and NS histologies (Ulbright 1999). The incidence of Type II germ cell tumors has doubled over the last four decades without an obvious explanation (Giwercman et al. 1993; McGlynn et al. 2005; Richiardi et al. 2004; Shah et al. 2007; Swerdlow et al. 1998).

The TGCTs described above are distinct from somatic cancers for two important reasons: Firstly, NS can differentiate into somatic, germ and extra-embryonic cell lineages and therefore is considered the only known totipotent solid cancer (Honecker et al. 2006; van de Geijn et al. 2009). Secondly, the cell of origin or 'cancer stem cell', CIS, is commonly assumed to originate during early fetal development from a germ cell in an undifferentiated environment (as opposed to the differentiated, adult tissue that most solid somatic cancers arise within) (reviewed by (Kristensen et al. 2008)). Due to the latter point, and given the obvious difficulty of directly studying CIS in humans, we now discuss other model systems that have been sought to investigate this pre-cursor lesion and its subsequent transformation into type II GCTs.

\section{Models of carcinoma in situ (CIS) and TGCT}

In mice, only models of the type I GCT teratoma exist; teratomas have been observed in several mouse strains including the 129/Sv wildtype mouse strain, as well as Kitl, Dead-end, Pten and Dmrt1 loss of function models (Heaney et al. 2008; Kimura et al. 2003; Krentz et al. 2009; Stevens 1967; Stevens 1984; Youngren et al. 2005). In each of these cases, susceptibility was increased on a 129/Sv background, suggesting strain-specific phenomena. Type III GCTs, spermatocytic seminomas, are believed to resemble canine TGCTs (Looijenga et al. 1994).

CIS, as well as type II TGCTs of SE and NS have not been observed in mice to date. As such, cell lines that resemble both SE and NS have largely been used for investigations into gene expression and behavior of these tumor sub-types. In addition to the lack of mouse models for CIS, CIS cells cannot be cultured and therefore no cell line exists for in vitro analysis.

The reason that mouse germ cells appear refractory to CIS and type II TGCT transformation is not yet known. Perhaps differences with respect to gene expression on the Y-chromosome have a bearing on the capacity of germ cells to transform: for example mouse Tspy (testis-specific protein Y-encoded) is non-functional but human TSPY is expressed in germ cells, CIS and SE (Li et al. 2007). Additionally, the timeframe of CIS transformation in human versus mouse is thought to play a significant role. In humans, both
Fig. 1. Developmental origin of human type II TGCT. During normal germ cell development pluripotency genes are turned off as fetal germ cells differentiate into spermatogonia. After puberty spermatogenesis begins and sperm is produced. Under pathological conditions, germ cells that fail to udergo correct spermatogenic differentiation and instead retain expression of pluripotencymarkers, develop into the precursor lesion carcinoma in situ (CIS). CIS cells remain dormant until puberty when they begin transformation into either seminoma (SE) or non-seminomas (NS), or both. Seminomas display fetal germ cell characteristics. NS include the most common subtype, embryonal carcinoma (EC), as well as yolk sac tumours (YST), teratomas (TE), choriocarcinomas (CH) or a mixture of these subtypes (mixed non-seminomas; mNS). Modified from Rajpert-De Meyts, 2006.

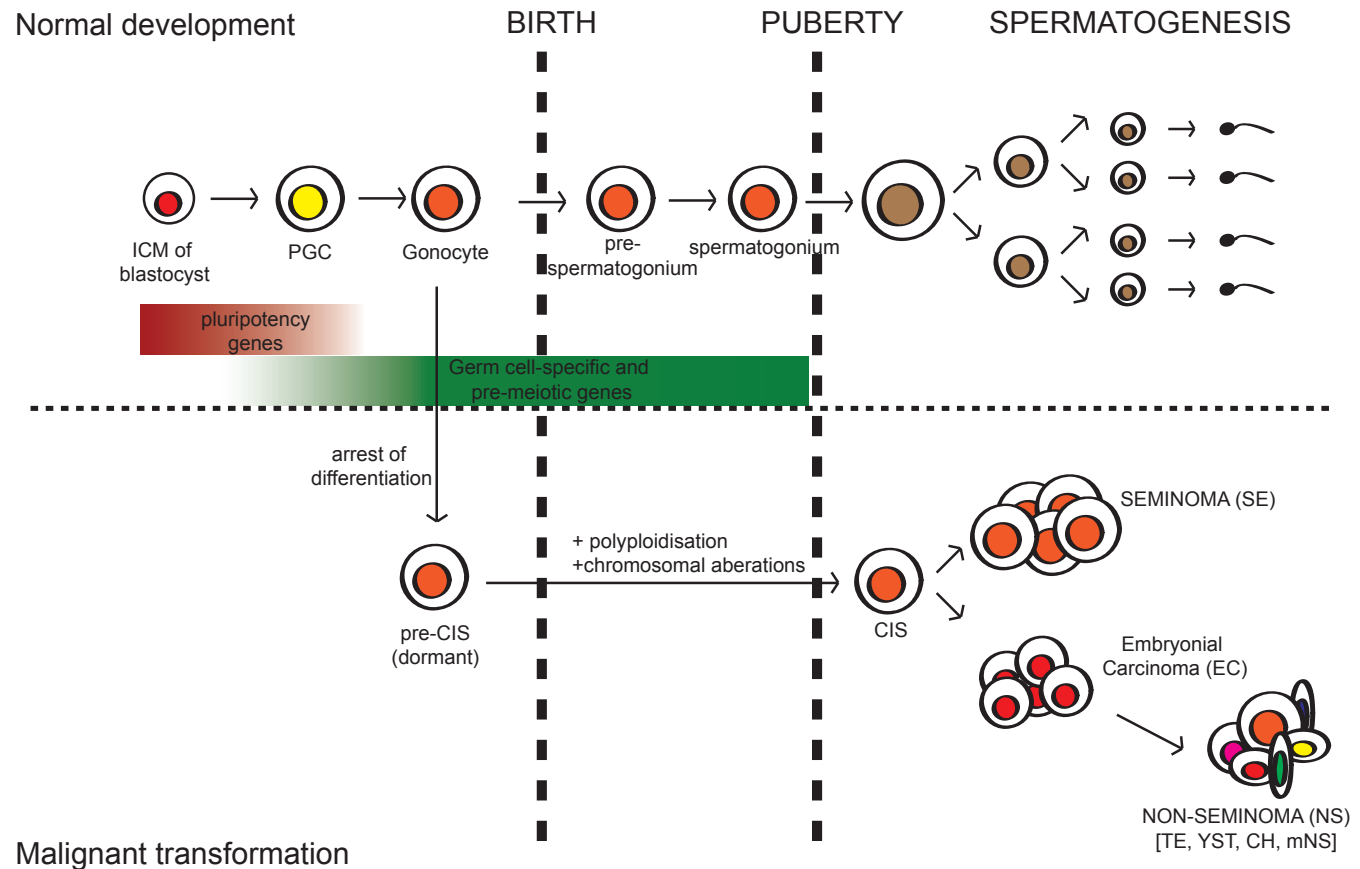


germ cells and CIS remain in a quiescent state for over a decade before proliferation resumes during puberty, presumably in response to hormonal triggers (Rajpert-De Meyts and Skakkebaek 1993). In mice, the period of germ cell quiescence lasts for little more than one week, making it unlikely that the environmental/niche cues that direct CIS transformation (along with the accumulation of substantial chromosomal abnormalities) have sufficient time to induce transformation.

\section{TGCT fetal origins hypothesis}

The fetal origins hypothesis asserts that CIS arises from fetal germ cells that have failed to differentiate correctly and that CIS is the precursor cell for type II TGCTs that arise after puberty (Skakkebaek et al. 1987). There is now abundant indirect evidence to support this hypothesis, discussed below. For a comprehensive reviews see (Kristensen et al. 2008; Rajpert-De Meyts et al. 2003).

\section{CIS cells resemble fetal germ cells (morphologically and transcriptionally)}

There is a strong morphological resemblance between CIS cells and gonocytes; both are large round cells with distinct nucleoli and similar ultrastructural characteristics (Nielsen et al. 1974; Sigg and Hedinger 1984; Skakkebaek et al. 1987). At the transcriptional level many markers are shared between CIS and fetal germ cells (Almstrup et al. 2005). Some of these include: placental-like alkaline phosphatase (Manivel et al. 1987), the proto-oncogene kit (Jorgensen et al. 1995), OCT3/4, NANOG (Hoei-Hansen et al. 2004a) AP-2 $\gamma$ (Hoei-Hansen et al. 2004b), DCN, IGFBP6, SFRP1, SALL1 and SOX17 (Hoei-Hansen et al. 2004a).

\section{CIS cells arise at the right place and time to originate from fetal germ cells}

After specification in the epiblast, the germ cells migrate through the hindgut toward the developing genital ridges. Incidences of extra-gonadal germ cell tumors (usually YST) often arise along the midline, consistent with the migratory path of fetal germ cells (Oosterhuis et al. 2007). CIS cells have been observed during fetal development also: mid-trimester fetuses with trisomy 21 were positive for markers of CIS (Jacobsen and Henriques 1992; Satge et al. 1996). Based on shared marker expression between $\mathrm{CIS}$ and germ cells, and because some genes are expressed only transiently during normal germ cell development, it has been estimated that $\mathrm{CIS}$ arises before the 9th week of gestation in humans (Jorgensen et al. 1995).

\section{CIS cells display pluripotent 'stem cell' characteristics}

In addition to sharing a transcriptional profile similar to germ cells, CIS cells also display stem cell characteristics, consistent with them being the precursor cell to TGCTs. Transcriptional analysis of $\mathrm{CIS}$ and ES cells revealed almost $50 \%$ shared gene transcription between the two populations (Hoei-Hansen et al. 2004a).

\section{CIS will usually transform to testicular cancer}

While CIS is commonly observed in parenchyma adjacent to TGCTs (in $90 \%$ of cases) (Jacobsen et al. 1981), in multiple cases previous identification of CIS has also been associated with patients subsequently developing TGCT. As such, identification of CIS results in a 50\% risk of developing TGCTs within 5 years and a $70 \%$ chance within 7 years (Linke et al. 2005; von der Maase et al. 1986).

\section{Predictions of the TGCT fetal origins hypothesis}

The fetal origins hypothesis was described over three decades ago and is now well accepted due to the vast body of supportive evidence described above. Based on this model, we can therefore predict that at least some of the molecular pathways affecting germ cell fetal development must be relevant to CIS transformation and adult testicular cancer. In the next section we outline signaling pathways involved in fetal germ cell development, which have also been implicated in TGCTs.

\section{Signaling pathways involved in germ cell development and tumorigenesis}

Over the past 2 decades several studies, including a recent genome wide association study (GWAS), have identified genetic pathways that account for about $15 \%$ of the genetic risk for TGCT. These include pathways known to control various aspects of germ cell development: kit signaling (KIT, KITL, SPRY4, BAK1), telomerase regulation (TERT, ARF7IP) and sex determination (DMRT1) (Turnbull and Rahman 2011).

\section{Kit - Kitl signaling}

Spontaneous mutations in kit ligand (Kitl; SCF) and its receptor (Kit) were implicated in germ cell development many years ago; homozygous mutations in either affect fetal germ cell migration and survival and result in infertility (Nishimune et al. 1980; Roskoski 2005). Kit protein, normally expressed by fetal germ cells, is detectable in CIS (Biermann et al. 2012; Rajpert-De Meyts and Skakkebaek 1994) and SE, but not in NS (Rajpert-De Meyts and Skakkebaek 1994). Interestingly, heterozygous deletion of Kitl in mice increases the TCGT susceptibility on the 129/Sv background (Heaney et al. 2008).

In humans, amplifications of genomic region containing KIT (chromosome 4q12) are associated with seminomas (Biermann et al. 2007; Looijenga et al. 2003; Murty et al. 1992) while deletions of the KITL genomic region (chromosome 12q22) are associated with NS. In all cases, mutations to KIT/KITL genomic regions are not identified within the precursor lesion CIS, suggesting that kit signaling determines the tumor progression after CIS initiation (Heaney et al. 2008).

Signaling pathways downstream from KIT/KITL have also been associated with TGCT susceptibility: two genes SPRY4 (Sprouty 4; chromosome 5q31) and BAK1 (BCL2-agonist/killer 1; chromosome $6 \mathrm{p} 21$ ) regulate mitogen-activated kinase signaling and proapoptotic pathways, respectively (Sasaki et al. 2003; Turnbull and Rahman 2011; Yan et al. 2000). These findings suggest that the larger network of KIT signaling is involved in the TGCT pathology.

\section{Telomerase function}

The extension of terminal chromosomal sequences by the enzyme telomerase occurs during every cell division. Reduced telomere function has been associated with genome instability (Hackett et al. 2001) whilst reactivation favors extended replicative lifespans of malignant cells (Fernandez-Garcia et al. 2008). The TERT gene encodes the catalytic subunit of the telomerase complex which, although normally absent in adult somatic tissues, 
is highly expressed in germ, stem and tumor cells. As such, high TERT expression was detected in undifferentiated TGCTs (SE) but absent from differentiated teratomas (Schrader et al. 2002). More recently, amplification of the genomic region harboring TERT (chromosome 5p15) was associated with TGCT predisposition (Turnbull and Rahman 2011). In the same study, ATF71P (activating transcription factor 7 interacting protein; chromosome 12p13), a protein that regulates expression of TERT, was also implicated in TGCT susceptibility (Turnbull and Rahman 2011).

\section{DMRT1}

DMRT1 (doublesex and mab-3 related transcription factor 1 ) is a transcription factor involved in testis differentiation during development in multiple species (Smith et al. 1999). Homozygous deletion of Dmrt 1 on a 129/Sv background increases teratoma formation to $90 \%$ compared to $1 \%$ in wildtype male mice (Krentz et al. 2009). In a human GWAS study, the genomic region harboring DMRT1 (chromosome 9p24) was found to be associated with TGCT susceptibility (Turnbull and Rahman 2011) and deletions of this region have previously been associated with impaired gonad development and TGCT formation (Barbaro et al. 2009; Livadas et al. 2003).

As mentioned, the above genetic pathways account for only $15 \%$ of heritable TGCT risk, and as such, new pathways regulating this process remain to be discovered. Recently, the Nodal signaling pathway has been shown to control mouse fetal germ cell pluripotency and was also found to be overexpressed in human TGCTs (Spiller et al. 2012). We now examine this signaling pathway in more detail and discuss the implications of this work.

\section{Nodal signaling in germ cells and cancer}

\section{The Nodal signaling pathway}

Nodal, a member of the TGF $\beta$ family, signals by binding to Activin receptors (serine/threonine kinase receptors, predominantly Alk4 (Acvr1b) and ActRIIA/B (Acvr2a/b)) in the presence of the obligate co-receptor, Cripto (also known as teratocarcinoma derived growth factor 1; TDGF-1) (Fig. 2). Binding of Nodal to Activin receptors causes them to phosphorylate (activate) the transcription factor Smad2 that, together with Smad4, regulates transcription of target genes (Chang et al. 2001; Schier and Shen 2000). Nodal up-regulates its own expression as well as the expression of two other TGF $\beta$ molecules, Lefty 1 and Lefty2, both of which act as dose-dependent feed-back inhibitors of the pathway (reviewed by (Schier 2009)). Nodal and its secreted Lefty inhibitors (Hamada et al. 2002) have been studied intensively for key roles in mesoderm generation, establishment of left-right asymmetry during gastrulation and specification of ventral cell identity during patterning of the nervous system (Shen 2007). All of these functions are Cripto-dependent.

Although most studies have focused on its roles during embryogenesis and in vitro stem cell generation, Cripto is emerging also as a regulator of normal tissue growth and remodeling in various tissues including mammary epithelial cells (Bianco et al. 2002), adipose tissue (Andersson et al. 2008), endometrium (Papageorgiou et al. 2009) and myoblasts (Kemaladewi et al. 2012), reviewed by (Gray and Vale 2012). Transient activation of Cripto is required for stem cell self-renewal and pluripotency, but continuous activation is associated with initiation or progression of cancer in many tissues including skin, pancreas, intestine and breast (reviewed by (Bianco et al. 2005)). Although Cripto is an obligate co-receptor for Nodal, it is also required for signaling by two other TGF $\beta$ molecules: growth derived factor 1 and 3 (GDF1, GDF3) (Chen et al. 2006; Cheng et al. 2003).

\section{Nodal regulates fetal germ cell pluripotency}

Recently Nodal signaling was shown to be active in $X Y$, but not $X X$, fetal germ cells during the period of sexual fate determination in the mouse embryo (Souquet et al. 2012; Spiller et al. 2012). Nodal, Cripto and the downstream modulator of Nodal signaling, SMAD2, were activated in XY germ cells, but not somatic cells, indicating autocrine Nodal signaling in those cells (Souquet et al. 2012; Spiller et al. 2012). Although all XY germ cells appear to express Cripto, the sub-population of germ cells with greatest potential to form embryonic germ cells at this stage expressed Cripto, Nodal, Lefty1 and Lefty2 at the highest levels. In purified germ cell culture, Cripto expression was induced by the male fate-promoting factor, FGF9 (Bowles et al. 2010) suggesting that this is how it comes to be upregulated in $X Y$ germ cells during fetal development. In a similar way, FGF2, one of the factors required for dedifferentiation of germ cells to EG cells (Durcova-Hills et al. 2006; Durcova-Hills and Surani 2008; Matsui and Tokitake 2009; Matsui et al. 1992; Resnick et al. 1992), was able to induce Cripto expression in vitro.

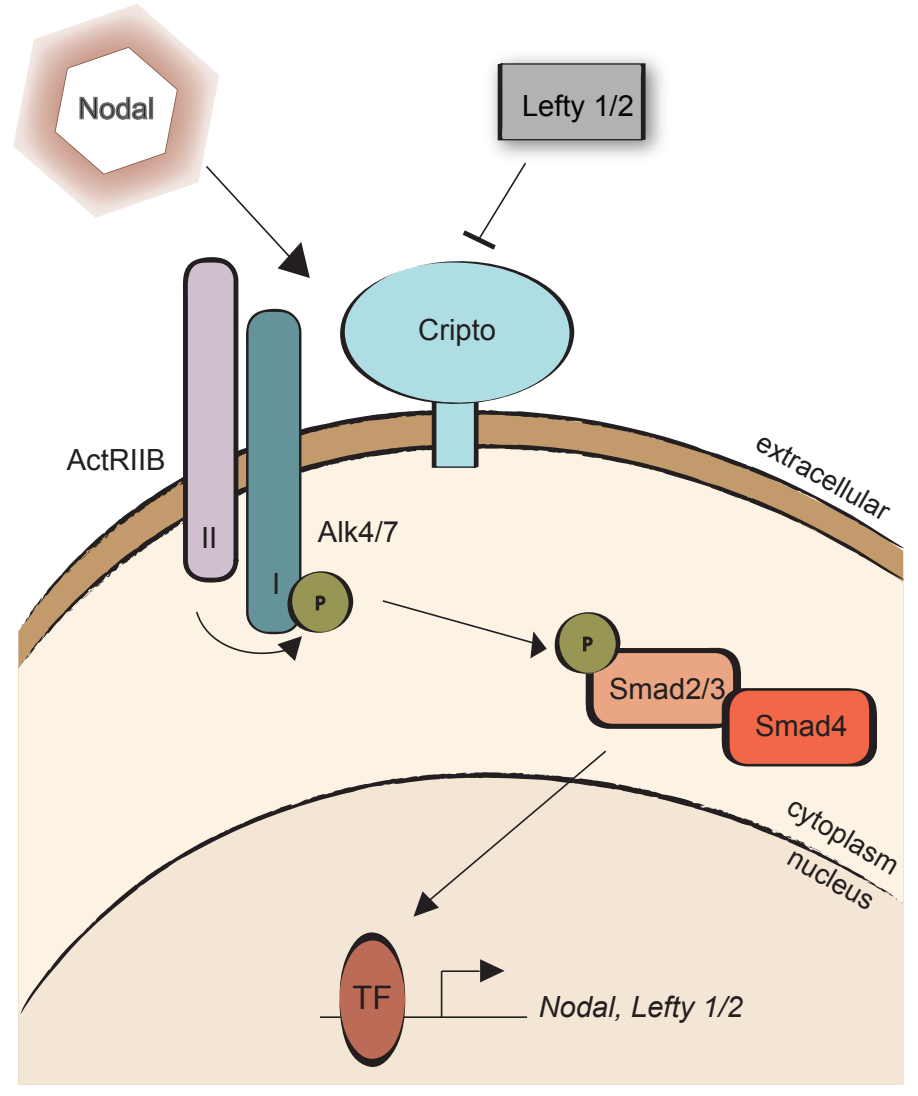

Fig. 2. Model of Nodal signaling. Nodal, a member of the TGF $\beta$ family, signals by binding to Activin receptors (predominantly ActRIIB, ALK4) in the presence of the obligate co-receptor, Cripto. Binding of Nodal to Activin receptors causes them to phosphorylate (activate) SMAD2 to regulate transcription of target genes. Lefty1 and Lefty2, also TGF $\beta$ molecules, repress the pathway in a dose-dependent manner. Nodal up-regulates its own expression as well as the expression of its inhibitors, Lefty1 and Lefty2. 
TABLE 1

\section{EXPRESSION OF NODAL PATHWAY GENES IN TYPE II TGCTS}

\begin{tabular}{llccc}
\multicolumn{1}{l}{ Tumor } & NODAL & CRIPTO & LEFTY1 \\
\hline Carcinoma in situ (CIS) & & + & + & + \\
Seminoma (SE) & & - & - & - \\
& Embryonal carcinoma (EC) & + & + & \\
\cline { 2 - 4 } & Mixed non-seminoma (mNS) & $+/-$ & $+/-$ & + Non-seminoma (NS) \\
\cline { 2 - 3 } & Yolk-sac tumor (YST) & + & + & + \\
& Choriocarcinoma (CH) & - & - & - \\
& Teratoma (TE) & - & - & - \\
\hline
\end{tabular}

Suppression of Nodal/Cripto signaling using the hypomorphic Nodaffioxffox mouse line (Lowe et al. 2001) led to a reduction in germ cell pluripotency makers and a decreased ability to form EG cells (Spiller et al. 2012).

These results suggested that the function of cell-autonomous Nodal/Cripto signaling in XY germ cell development is to maintain germ cells in a state of pluripotency, thereby avoiding differentiation for a time (Spiller et al. 2012), a role akin to that seen in human ES cells (James et al. 2005). In contrast to these findings however, another study concluded that disruption of Activin/Nodal signaling affected fetal germ cell meiosis (although pluripotency was not investigated) (Souquet et al. 2012). In that study, Activin/Nodal inhibitors disrupted Nodal signaling in germ cells but also Activin signaling in somatic cells, so it is possible that the observed meiosis is the result of inadvertent disruption of the gonadal environment: Activin is normally required for the induction of germ cell mitotic arrest and differentiation (Mendis et al. 2010). Complete Nodal deletion in germ cells may be required to clarify whether the main role of Nodal signaling is to maintain pluripotency or to prevent meiosis. In the hypomorphic Nodalfioxffox mouse line, no ectopic entry into meiosis was observed (Spiller et al. 2012)

\section{Nodal signaling pathway genes are over-expressed in TGCTs}

Having established a role for endogenous Nodal signaling during normal germ cell pluripotency, and based on the fetal origins hypothesis, it was hypothesized that this pathway may be mis-regulated in cases of human TGCT (Spiller et al. 2012). Consistent with a role in pluripotency maintenance in fetal germ cells, CRIPTO, NODAL and downstream target $L E F T Y 1$ expression positively correlated with CIS presence in testis biopsies and in the undifferentiated NS (EC and YST) (summarized in Table 1; (Spiller et al. 2012)). The finding that a developmental pathway that controls pluripotency in fetal germ cells is mis-regulated in cases of human TGCTs provides further support for the fetal origins hypothesis.

\section{Implications for normal germ cell development}

As discussed, during fetal development in the testis, $X Y$ germ cells express Nodal, Cripto and also Lefty 1 and Lefty2 (Souquet et al. 2012; Spiller et al. 2012). Lefty1 and Lefty2 are known direct downstream targets of Nodal signaling and their transcription in germ cells confirms that these cells are responding to Nodal signaling (Branford and Yost 2002; Feldman et al. 2002; Meno et al. 1999). During gastrulation and neurogenesis, Leftys play important roles in limiting the range of Nodal signaling and fine-tuning the Nodal concentration gradient via a reaction-diffusion mechanism (Schier 2009; Shen 2007). Hence, the question arises as to the function of Lefty during testicular germ cell development, given that only germ cells express the co-receptor Cripto and that positional information does not seem to be essential for determining germ cell behavior in the developing testis. It is possible that Leftys act to prevent non-Cripto dependent Nodal action outside of the germ cell compartment of the testis. It will be of interest to test the consequences of genetically or pharmaceutically manipulating Lefty activity during gonadal development. It will also be informative to determine whether any Cripto-independent role for Nodal exists, and vice versa, using Cripto deletion in germ cells (Liguori et al. 2008). Given the early requirement for both Nodal and Cripto during gastrulation, conditional deletion of these genes within fetal germ cells will be required.

\section{Implications for embryonic stem (ES) and embryonic germ (EG) cells}

Activin/Nodal signaling is now well established in the maintenance of pluripotency of human and rabbit ES cells (Honda et al. 2009; James et al. 2005; Vallier et al. 2004) and mouse and pig epiblast stem cells (EpiSC), which are derived from the epiblast of post-implantation, pre-gastrula embryos (Alberio et al. 2010; Brons et al. 2007; Tesar et al. 2007). EpiSCs, like human and rabbit ES cells, require the presence of FGF2 and Activin in order to maintain pluripotency (Brons et al. 2007; Chou et al. 2008; Tesar et al. 2007). They express Oct4, Sox2, Nodal and Nanog as well as low levels of the ES cell and germ cell marker Stella, presumably due to their epigenetic status. In such contexts Nodal is known to regulate expression of the homeodomain transcription factor Nanog (Chambers et al. 2003; Mitsui et al. 2003). Oct4, another target of Nodal signaling and activator of Cripto transcription (Watanabe et al. 2010), together with Sox2 and Nanog comprise the gene regulatory network sufficient for pluripotency maintenance in ES cells. In contrast, mouse ES cell maintenance only requires the cytokine LIF, a member of interleukin- 6 family that signals via the gp130 receptor to control the Jak-Stat pathway (Loh et al. 2006). Given that endogenous Nodal signaling maintains pluripotency in fetal germ cells (Spiller et al. 2012), it seems that these cells are more similar to human and rabbit ES cells and mouse and pig EpiECs, than to mouse ES cells. Such properties may be important when considering re-programming of ES cells to germ cells and vice-versa.

The generation of EG colonies from primordial germ cells is testament to their stem cell potential as these colonies closely resemble ES cells and can contribute to all three embryonic germ layers. EG derivation is induced by the presence of three factors: LIF, FGF2 and KITL (Durcova-Hills et al. 2006; Durcova-Hills and Surani 2008; Matsui and Tokitake 2009; Matsui et al. 1992; Resnick et al. 1992). Interestingly, FGF2 is able to upregulate Cripto expression in isolated $X Y$ and $X X$ germ cells (Spiller et al. 2012): since FGF2 is required only during the first 24 hours of EG cell derivation (Durcova-Hills et al. 2006) it is possible that its major role is to prime the germ cells for reprogramming by triggering Cripto expression. The male-specific endogenous expression of Cripto may underlie the slightly greater propensity of $X Y$ germ cells to generate EG cells when compared with XX germ cells, as has been reported in some studies (Kimura et al. 2008; Labosky et al. 1994).

It is important to note that only small populations of germ cells are able to respond to the signaling molecules that induce EG cell derivation (Durcova-Hills and Surani 2008). This phenomenon is being reflected in many recent findings highlighting the heterogeneity of the fetal germ cell population with respect to gene and cellsurface marker expression (Matsui and Tokitake 2009; Spiller et al. 
2012). Sub-populations of fetal germ cells with differing potentials for pluripotency and/or differentiation would also suggest that inherent differences in these cells contribute to the potential for CIS transformation, in addition to disturbances in the local niche environment.

\section{Implications for germ cell transformation to CIS}

The findings of Spiller et al. (2012) led us to hypothesize that during human CIS formation, CRIPTO expression is maintained or re-activated, triggering upregulation of Nodal signaling, aberrant expression of pluripotency markers and subsequent progression to the oncogenic state. It is possible that ectopic expression of CRIPTO makes such germ cells refractory to normal differentiation cues of the TGF $\beta$ signaling pathway as has been observed in other systems (Gray et al. 2003; Gray et al. 2006). In human cancers, CRIPTO has emerged as an oncogenic growth factor, controlling proliferation, migration and survival (Bianco et al. 2005; Wechselberger et al. 2005). CRIPTO functions as a dominant transforming gene when over-expressed in the NOG-8 mouse mammary epithelial cell line or NIH/3T3 fibroblasts (Ciccodicola et al. 1989). Despite the multi-hit hypothesis for tumor formation, our understanding of the biology of Nodal/Cripto signaling in germ cells so far suggests that expression of Cripto may be sufficient to endow germ cells with sufficient tumorigenic capacity to trigger CIS.

\section{Implications for CIS transformation into seminoma vs. non- seminoma}

CIS cells have the potential to develop down multiple pathways: germ-cell like tumor (SE), pluripotent tumors (EC) and differentiated teratomas and extra-embryonic components ( $\mathrm{CH}, \mathrm{YST})$. The mechanism by which a CIS cell is induced to develop into either SE or NS (or both) is unclear. Over-expression of Nodal signaling genes was detected in biopsies containing CIS and the NS tumors EC and YST (Spiller et al. 2012). This finding is somewhat unusual given that genes expressed in CIS are often also expressed in SE given their close resemblance to fetal germ cells. The finding that CRIPTO is expressed by CIS but is switched off during progression into SE suggests that Nodal signaling in this context is highly dependent on the stem cell niche of the CIS cell environment. It is possible that, as seems to be the case with the generation of EG cells in vitro, expression of CRIPTO/NODAL makes human germ cells more susceptible to signals that trigger complete dedifferentiation and tumor formation. Perhaps the CIS cells that lack such dedifferentiation factors in their environmental niche are the ones that progress to SE, a cancer characterised by expression of fetal germ cell genes.

Alternatively (or additionally), it is intriguing to speculate that levels of CRIPTO expression in a given CIS cell are instructive, rather than passive, and determine the fate of CIS transformation into SE versus NS. Indeed, such heterogeneous regulation of CRIPTO (at both the level of promoter methylation and protein expression) in the EC cell line NTERA2, correlated Cripto ${ }^{\text {High }}$-expressing cells with an undifferentiated state and greatest tumorigenic potential (Watanabe et al. 2010).

Looking at the broader Nodal signaling pathway, it is possible that NODAL and CRIPTO act as oncogenes during development of CIS and TGCTs whilst LEFTY genes may encode tumor-suppressors. This hypothesis is supported by the observation that NODAL, CRIPTO and LEFTY expression are elevated in the YST subtype of NS but only NODAL and CRIPTO expression are elevated in the more dangerous form, EC. If Nodal signaling is triggered but the negative regulator of the pathway, LEFTY, is not expressed, a highly pluripotent phenotype should result (Postovit et al. 2008).

Given that Nodal/Cripto signaling is a key developmental pathway essential for gastrulation, it is unlikely that gene mutations will be discovered within this pathway in CIS and TGCTs. Rather, levels of gene expression are likely altered during the process of transformation. Investigation of the methylation status of Nodal/Cripto pathway gene promoters in CIS and TGCT pathologies may shed some light on the regulation of gene expression in these contexts: hypomethylation of oncogenes and hypermethylation of tumor-suppressor genes are commonly seen in cancer. Additionally, analysis of the CRIPTO promoter during normal fetal germ cell development may provide clues as to how CRIPTO expression is regulated under normal circumstances.

\section{Future directions}

Confirmation that the Nodal/Cripto pathway is active during normal human fetal germ cell development and that the Cripto protein is expressed on the surface of CIS cells should now be sought. Importantly, investigation of Cripto expression in the rare instance when fetal CIS biopsies are available would assist in confirming whether CRIPTO expression is maintained or instead re-activated during CIS development. If these studies suggest that CRIPTO expression is maintained, the developmental window for fetal gonocyte transformation into CIS could be narrowed to the period of endogenous Cripto expression during development (ie. 12.5 - $14.5 \mathrm{dpc}$ in the mouse). A better understanding of how Nodal/Cripto signaling is regulated during fetal germ cell development, including FGF control of this process, will help us to understand how Cripto is retained or re-activated during malignant transformation.

\section{Conclusions}

We rely on germ cells for fertility - the propagation of our species. Because these cells are generally specified and matured correctly, the potential they hold for reversion to pluripotent and tumorigenic states is perhaps not often fully appreciated. A fine balance between $X Y$ germ cell pluripotency, proliferation and quiescence must be achieved within a relative short window during human gestation: uncontrolled proliferation results in cancer whereas failure to differentiate can result in infertility. We currently know little of how these processes are balanced, although we predict, based on the fetal origins hypothesis, that developmental pathways controlling germ cell development are involved. The discovery that the Nodal/ Cripto signaling pathway controls normal germ cell pluripotency but is activated ectopically in the most deadly forms of TGCTs in humans may have provided a starting point for further investigations into this process. Indeed, only $15 \%$ of TGCTs can be explained by gene amplifications/deletions so far, and so the search must continue for new mechanisms of regulation. Understanding such molecular pathways and factors that control or maintain germ cell differentiation or stemness will have important implications for both fertility and cancer treatment in the future.

\section{References}

ADAMI, H.O., BERGSTROM, R., MOHNER, M., ZATONSKI, W., STORM, H., EKBOM, A., TRETLI, S., TEPPO, L., ZIEGLER, H., RAHU, M. et al. (1994). Testicular cancer 
in nine northern European countries. Int J Cancer 59: 33-38.

ALBERIO, R., CROXALL, N. and ALLEGRUCCI, C. (2010). Pig epiblast stem cells depend on activin/nodal signaling for pluripotency and self-renewal. Stem Cells Dev 19: 1627-1636.

ALMSTRUP, K., HOEI-HANSEN, C.E., NIELSEN, J.E., WIRKNER, U., ANSORGE, W., SKAKKEBAEK, N.E., RAJPERT-DE MEYTS, E. and LEFFERS, H. (2005). Genome-wide gene expression profiling of testicular carcinoma in situ progression into overt tumours. Br J Cancer 92: 1934-1941.

ANDERSSON, O., KORACH-ANDRE, M., REISSMANN, E., IBANEZ, C.F. and BERTOLINO, P. (2008). Growth/differentiation factor 3 signals through ALK7 and regulates accumulation of adipose tissue and diet-induced obesity. Proc Natl Acad Sci USA 105: 7252-7256.

BARBARO, M., BALSAMO, A., ANDERLID, B.M., MYHRE, A.G., GENNARI, M., NICOLETTI, A., PITTALIS, M.C., OSCARSON, M. and WEDELL, A. (2009). Characterization of deletions at $9 p$ affecting the candidate regions for sex reversal and deletion 9p syndrome by MLPA. Eur J Hum Genet 17: 1439-1447.

BARRIOS, F., FILIPPONI, D., PELLEGRINI, M., PARONETTO, M.P., DI SIENA, S., GEREMIA, R., ROSSI, P., DE FELICI, M., JANNINI, E.A. and DOLCI, S. (2010). Opposing effects of retinoic acid and FGF9 on Nanos2 expression and meiotic entry of mouse germ cells. J Cell Sci 123: 871-880.

BIANCO, C., ADKINS, H.B., WECHSELBERGER, C., SENO, M., NORMANNO, N., DE LUCA, A., SUN, Y., KHAN, N., KENNEY, N., EBERT, A. et al. (2002). Cripto-1 activates nodal- and ALK4-dependent and -independent signaling pathways in mammary epithelial Cells. Mol Cell Biol 22: 2586-2597.

BIANCO, C., STRIZZI, L., EBERT, A., CHANG, C., REHMAN, A., NORMANNO, N., GUEDEZ, L., SALLOUM, R., GINSBURG, E., SUN, Y. et al. (2005). Role of human cripto-1 in tumor angiogenesis. J Natl Cancer Inst 97: 132-141.

BIERMANN, K., HEUKAMP, L.C., STEGER, K., ZHOU, H., FRANKE, F.E., GUETGEMANN, I., SONNACK, V., BREHM, R., BERG, J., BASTIAN, P.J. et al. (2007). Gene expression profiling identifies new biological markers of neoplastic germ cells. Anticancer Res 27: 3091-3100.

BIERMANN, K., STOOP, H. and LOOIJENGA, L. (2012). c-KIT protein expression does not discriminate neoplastic from non-neoplastic intratubular germ cells. Histopathology 60: 1017-1019.

BOWLES, J., FENG, C.W., SPILLER, C., DAVIDSON, T.L., JACKSON, A. and KOOPMAN, P. (2010). FGF9 suppresses meiosis and promotes male germ cell fate in mice. Dev Cell 19: 440-449.

BOWLES, J., KNIGHT, D., SMITH, C., WILHELM, D., RICHMAN, J., MAMIYA, S., YASHIRO, K., CHAWENGSAKSOPHAK, K., WILSON, M.J., ROSSANT, J. et al. (2006). Retinoid signaling determines germ cell fate in mice. Science 312: 596-600.

BRANFORD, W.W. and YOST, H.J. (2002). Lefty-dependent inhibition of Nodal- and Wnt-responsive organizer gene expression is essential for normal gastrulation. Curr Biol 12: 2136-2141.

BRONS, I.G., SMITHERS, L.E., TROTTER, M.W., RUGG-GUNN, P., SUN, B., CHUVA DESOUSALOPES, S.M., HOWLETT, S.K., CLARKSON, A.,AHRLUND-RICHTER, L., PEDERSEN, R.A. et al. (2007). Derivation of pluripotent epiblast stem cells from mammalian embryos. Nature 448: 191-195.

CHAMBERS, I., COLBY, D., ROBERTSON, M., NICHOLS, J., LEE, S., TWEEDIE, S. and SMITH, A. (2003). Functional expression cloning of Nanog, a pluripotency sustaining factor in embryonic stem cells. Cell 113: 643-655.

CHANG, H., LAU, A.L. and MATZUK, M.M. (2001). Studying TGF-beta superfamily signaling by knockouts and knockins. Mol Cell Endocrinol 180: 39-46.

CHEN, C., WARE, S.M., SATO, A., HOUSTON-HAWKINS, D.E., HABAS, R., MATZUK, M.M., SHEN, M.M. and BROWN, C.W. (2006). The Vg1-related protein Gdf3 acts in a Nodal signaling pathway in the pre-gastrulation mouse embryo. Development 133: 319-329.

CHENG, S.K., OLALE, F., BENNETT, J.T., BRIVANLOU, A.H. and SCHIER, A.F. (2003). EGF-CFC proteins are essential coreceptors for the TGF-beta signals Vg1 and GDF1. Genes Dev 17: 31-36.

CHOU, Y.F., CHEN, H.H., EIJPE, M., YABUUCHI, A., CHENOWETH, J.G., TESAR, P., LU, J., MCKAY, R.D. and GEIJSEN, N. (2008). The growth factor environment defines distinct pluripotent ground states in novel blastocyst-derived stem cells. Cell 135: 449-461.

CICCODICOLA, A., DONO, R., OBICI, S., SIMEONE, A., ZOLLO, M. and PERSICO, M.G. (1989). Molecular characterization of a gene of the 'EGF family' expressed in undifferentiated human NTERA2 teratocarcinoma cells. EMBO J8: 1987-1991.
DURCOVA-HILLS, G., ADAMS, I.R., BARTON, S.C., SURANI, M.A. and MCLAREN A. (2006). The role of exogenous fibroblast growth factor-2 on the reprogramming of primordial germ cells into pluripotent stem cells. Stem Cells 24: 1441-1449.

DURCOVA-HILLS, G. and SURANI, A. (2008). Reprogramming primordial germ cells (PGC) to embryonic germ (EG) cells. Curr Protoc Stem Cell Bio/Chapter 1:Unit1A3.

FELDMAN, B., CONCHA, M.L., SAUDE, L., PARSONS, M.J., ADAMS, R.J., WILSON, S.W. and STEMPLE, D.L. (2002). Lefty antagonism of Squint is essential for normal gastrulation. Curr Biol 12: 2129-2135.

FERNANDEZ-GARCIA, I., ORTIZ-DE-SOLORZANO, C. and MONTUENGA, L.M. (2008). Telomeres and telomerase in lung cancer. J Thorac Oncol 3: 1085-1088.

GIWERCMAN, A., CARLSEN, E., KEIDING, N. and SKAKKEBAEK, N.E. (1993). Evidence for increasing incidence of abnormalities of the human testis: a review. Environ Health Perspect 101 Suppl 2: 65-71.

GRAY, P.C., HARRISON, C.A. and VALE, W. (2003). Cripto forms a complex with activin and type II activin receptors and can block activin signaling. Proc Natl Acad Sci USA 100: 5193-5198.

GRAY, P.C., SHANI, G., AUNG, K., KELBER, J. and VALE, W. (2006). Cripto binds transforming growth factor beta (TGF-beta) and inhibits TGF-beta signaling. Mol Cell Biol 26: 9268-9278.

GRAY, P.C. and VALE, W. (2012). Cripto/GRP78 modulation of the TGF-beta pathway in development and oncogenesis. FEBS Lett 586: 1836-1845.

HACKETT, J.A., FELDSER, D.M. and GREIDER, C.W. (2001). Telomere dysfunction increases mutation rate and genomic instability. Cell 106: 275-286.

HAMADA, H., MENO, C., WATANABE, D. and SAIJOH, Y. (2002). Establishment of vertebrate left-right asymmetry. Nat Rev Genet 3: 103-113.

HEANEY, J.D., LAM, M.Y., MICHELSON, M.V. and NADEAU, J.H. (2008). Loss of the transmembrane but not the soluble kit ligand isoform increases testicular germ cell tumor susceptibility in mice. Cancer Res 68: 5193-5197.

HEIMDAL, K., OLSSON, H., TRETLI, S., FOSSA, S.D., BORRESEN, A.L. and BISHOP, D.T. (1997). A segregation analysis of testicular cancer based on Norwegian and Swedish families. Br J Cancer 75: 1084-1087.

HEMMINKI, K. and LI, X. (2004). Familial risk in testicular cancer as a clue to a heritable and environmental aetiology. Br J Cancer 90: 1765-1770.

HILSCHER, W. (1974). [Kinetics of prespermatogenesis and spermatogenesis]. Verh Anat Ges 68: 39-62.

HOEI-HANSEN, C.E., NIELSEN, J.E., ALMSTRUP, K., HANSEN, M.A., SKAKKEBAEK, N.E., RAJPERT-DEMEYTS, E. and LEFFERS, H. (2004a). Identification of genes differentially expressed in testes containing carcinoma in situ. Mol Hum Reprod 10: 423-431.

HOEI-HANSEN, C.E., NIELSEN, J.E., ALMSTRUP, K., SONNE, S.B., GRAEM, N., SKAKKEBAEK, N.E., LEFFERS, H. and RAJPERT-DE MEYTS, E. (2004b) Transcription factor AP-2gamma is a developmentally regulated marker of testicular carcinoma in situ and germ cell tumors. Clin Cancer Res 10: 8521-8530.

HONDA, A., HIROSE, M. and OGURA, A. (2009). Basic FGF and Activin/Nodal but not LIF signaling sustain undifferentiated status of rabbit embryonic stem cells. Exp Cell Res 315: 2033-2042

HONECKER, F., STOOP, H., MAYER, F., BOKEMEYER, C., CASTRILLON, D.H., LAU, Y.F., LOOIJENGA, L.H. and OOSTERHUIS, J.W. (2006). Germ cell lineage differentiation in non-seminomatous germ cell tumours. J Pathol 208: 395-400.

HORWICH, A., SHIPLEY, J. and HUDDART, R. (2006). Testicular germ-cell cancer. Lancet 367: 754-765.

JACOBSEN, G.K., HENRIKSEN, O.B. and VON DER MAASE, H. (1981). Carcinoma in situ of testicular tissue adjacent to malignant germ-cell tumors: a study of 105 cases. Cancer 47: 2660-2662.

JACOBSEN, G.K. and HENRIQUES, U.V. (1992). A fetal testis with intratubular germ cell neoplasia (ITGCN). Mod Pathol 5: 547-549.

JAMES, D., LEVINE, A.J., BESSER, D. and HEMMATI-BRIVANLOU, A. (2005) TGFbeta/activin/nodal signaling is necessary for the maintenance of pluripotency in human embryonic stem cells. Development 132: 1273-1282.

JIANG, L.I. and NADEAU, J.H. (2001). 129/Sv mice--a model system for studying germ cell biology and testicular cancer. Mamm Genome 12: 89-94.

JORGENSEN, N., RAJPERT-DE MEYTS, E., GRAEM, N., MULLER, J., GIWERCMAN, A. and SKAKKEBAEK, N.E. (1995). Expression of immunohistochemical markers for testicular carcinoma in situ by normal human fetal germ cells. Lab Invest 72: 223-231. 
KEMALADEWI, D.U., DE GORTER, D.J., AARTSMA-RUS, A., VAN OMMEN, G.J., TEN DIJKE, P., T HOEN, P.A. and HOOGAARS, W.M. (2012). Cell-type specific regulation of myostatin signaling. FASEB J 26: 1462-1472.

KIMURA, T., SUZUKI, A., FUJITA, Y., YOMOGIDA, K., LOMELI, H., ASADA, N., IKEUCHI, M., NAGY, A., MAK, T.W. and NAKANO, T. (2003). Conditional loss of PTEN leads to testicular teratoma and enhances embryonic germ cell production. Development 130: 1691-1700.

KIMURA, T., TOMOOKA, M., YAMANO, N., MURAYAMA, K., MATOBA, S., UMEHARA, H., KANAI, Y. and NAKANO, T. (2008). AKT signaling promotes derivation of embryonic germ cells from primordial germ cells. Development 135: 869-879.

KOUBOVA, J., MENKE, D.B., ZHOU, Q., CAPEL, B., GRISWOLD, M.D. and PAGE, D.C. (2006). Retinoic acid regulates sex-specific timing of meiotic initiation in mice. Proc Natl Acad Sci USA 103: 2474-2479.

KRENTZ, A.D., MURPHY, M.W., KIM, S., COOK, M.S., CAPEL, B., ZHU, R., MATIN, A., SARVER, A.L., PARKER, K.L., GRISWOLD, M.D. etal. (2009). The DM domain protein DMRT1 is a dose-sensitive regulator of fetal germ cell proliferation and pluripotency. Proc Natl Acad Sci USA 106: 22323-22328.

KRISTENSEN, D.M., SONNE, S.B., OTTESEN, A.M., PERRETT, R.M., NIELSEN, J.E., ALMSTRUP, K., SKAKKEBAEK, N.E., LEFFERS, H. and RAJPERT-DE MEYTS, E. (2008). Origin of pluripotent germ cell tumours: the role of microenvironment during embryonic development. Mol Cell Endocrinol 288: 111-118.

LABOSKY, P.A., BARLOW, D.P. and HOGAN, B.L. (1994). Mouse embryonic germ $(E G)$ cell lines: transmission through the germline and differences in the methylation imprint of insulin-like growth factor 2 receptor (Igf2r) gene compared with embryonic stem (ES) cell lines. Development 120: 3197-3204.

LI, Y., TABATABAI, Z.L., LEE, T.L., HATAKEYAMA, S., OHYAMA, C., CHAN, W.Y., LOOIJENGA, L.H. and LAU, Y.F. (2007). The Y-encoded TSPY protein: a significant marker potentially plays a role in the pathogenesis of testicular germ cell tumors. Hum Pathol 38: 1470-1481.

LIGUORI, G.L., BORGES, A.C., D'ANDREA, D., LIGUORO, A., GONCALVES, L., SALGUEIRO, A.M., PERSICO, M.G. and BELO, J.A. (2008). Cripto-independent Nodal signaling promotes positioning of the A-P axis in the early mouse embryo. Dev Biol 315: 280-289.

LINKE, J., LOY, V. and DIECKMANN, K.P. (2005). Prevalence of testicular intraepithelial neoplasia in healthy males. J Urol 173: 1577-1579.

LIVADAS, S., MAVROU, A., SOFOCLEOUS, C., VAN VLIET-CONSTANTINIDOU, C., DRACOPOULOU, M. and DACOU-VOUTETAKIS, C. (2003). Gonadoblastoma in a patient with del(9)(p22) and sex reversal: report of a case and review of the literature. Cancer Genet Cytogenet 143: 174-177.

LOH, Y.H., WU, Q., CHEW, J.L., VEGA, V.B., ZHANG, W., CHEN, X., BOURQUE, G., GEORGE, J., LEONG, B., LIU, J. et al. (2006). The Oct4 and Nanog transcription network regulates pluripotency in mouse embryonic stem cells. Nat Genet 38: 431-440

LOOIJENGA, L.H., DE LEEUW, H., VAN OORSCHOT, M., VAN GURP, R.J., STOOP, H., GILLIS, A.J., DE GOUVEIABRAZAO, C.A., WEBER, R.F., KIRKELS, W.J., VAN DIJK, T. et al. (2003). Stem cell factor receptor (c-KIT) codon 816 mutations predict development of bilateral testicular germ-cell tumors. Cancer Res 63: 7674-7678.

LOOIJENGA, L.H., OLIE, R.A., VAN DER GAAG, I., VAN SLUIJS, F.J., MATOSKA, J., PLOEM-ZAAIJER, J., KNEPFLE, C. and OOSTERHUIS, J.W. (1994). Seminomas of the canine testis. Counterpart of spermatocytic seminoma of men? Lab Invest 71: 490-496.

LOWE, L.A., YAMADA, S. and KUEHN, M.R. (2001). Genetic dissection of nodal function in patterning the mouse embryo. Development 128: 1831-1843.

MANIVEL, J.C., JESSURUN, J., WICK, M.R. and DEHNER, L.P. (1987). Placental alkaline phosphatase immunoreactivity in testicular germ-cell neoplasms. Am J Surg Pathol 11: 21-29.

MATSUI, Y. and TOKITAKE, Y. (2009). Primordial germ cells contain subpopulations that have greater ability to develop into pluripotential stem cells. Dev Growth Differ 51: 657-667.

MATSUI, Y., ZSEBO, K. and HOGAN, B.L. (1992). Derivation of pluripotential embryonic stem cells from murine primordial germ cells in culture. Cell 70: 841-847.

MCGLYNN, K.A., DEVESA, S.S., GRAUBARD, B.I. and CASTLE, P.E. (2005). Increasing incidence of testicular germ cell tumors among black men in the United States. J Clin Oncol 23: 5757-5761.

MCLAREN, A. and SOUTHEE, D. (1997). Entry of mouse embryonic germ cells into meiosis. Dev Biol 187: 107-113.
MENDIS, S.H., MEACHEM, S.J., SARRAJ, M.A. and LOVELAND, K.L. (2010). Activin A Balances Sertoli and Germ Cell Proliferation in the Fetal Mouse Testis. Biol Reprod.

MENO, C., GRITSMAN, K., OHISHI, S., OHFUJI, Y., HECKSCHER, E., MOCHIDA, K., SHIMONO, A., KONDOH, H., TALBOT, W.S., ROBERTSON, E.J. et al. (1999). Mouse Lefty2 and zebrafish antivin are feedback inhibitors of nodal signaling during vertebrate gastrulation. Mol Cell 4: 287-298.

MITSUI, K., TOKUZAWA, Y., ITOH, H., SEGAWA, K., MURAKAMI, M., TAKAHASHI, K., MARUYAMA, M., MAEDA, M. and YAMANAKA, S. (2003). The homeoprotein Nanog is required for maintenance of pluripotency in mouse epiblast and ES cells. Cell 113: 631-642.

MURTY, V.V., HOULDSWORTH, J., BALDWIN, S., REUTER, V., HUNZIKER, W. BESMER, P., BOSL, G. and CHAGANTI, R.S. (1992). Allelic deletions in the long arm of chromosome 12 identify sites of candidate tumor suppressor genes in male germ cell tumors. Proc Natl Acad Sci USA 89: 11006-11010.

NIELSEN, H., NIELSEN, M. and SKAKKEBAEK, N.E. (1974). The fine structure of possible carcinoma-in-situ in the seminiferous tubules in the testis of four infertile men. Acta Pathol Microbiol Scand A 82: 235-248

NISHIMUNE, Y., HANEJI, T. and KITAMURA, Y. (1980). The effects of steel mutation on testicular germ cell differentiation. J Cell Physiol 105: 137-141.

OOSTERHUIS, J.W., STOOP, H., HONECKER, F. and LOOIJENGA, L.H. (2007) Why human extragonadal germ cell tumours occur in the midline of the body: old concepts, new perspectives. Int J Androl 30: 256-263; discussion 263-254.

PAPAGEORGIOU, I., NICHOLLS, P.K., WANG, F., LACKMANN, M., MAKANJI, Y., SALAMONSEN, L.A., ROBERTSON, D.M. and HARRISON, C.A. (2009). Expression of nodal signalling components in cycling human endometrium and in endometrial cancer. Reprod Biol Endocrinol 7: 122.

POSTOVIT, L.M., MARGARYAN, N.V., SEFTOR, E.A., KIRSCHMANN, D.A., LIPAVSKY, A., WHEATON, W.W., ABBOTT, D.E., SEFTOR, R.E. and HENDRIX, M.J. (2008). Human embryonic stem cell microenvironment suppresses the tumorigenic phenotype of aggressive cancer cells. Proc Natl Acad Sci USA 105 4329-4334.

RAJPERT-DE-MEYTS, E. (2006). Developmental model for the pathogenesis of testicular carcinoma in situ: genetic and environmental aspects. Hum Reprod Update 12: 303-323.

RAJPERT-DE MEYTS, E., BARTKOVA, J., SAMSON, M., HOEI-HANSEN, C.E., FRYDELUND-LARSEN, L., BARTEK, J. and SKAKKEBAEK, N.E. (2003). The emerging phenotype of the testicular carcinoma in situ germ cell. APMIS 111: 267-278; discussion 278-269.

RAJPERT-DE MEYTS, E. and SKAKKEBAEK, N.E. (1993). The possible role of sex hormones in the development of testicular cancer. Eur Urol 23: 54-59; discussion $60-51$

RAJPERT-DE MEYTS, E. and SKAKKEBAEK, N.E. (1994). Expression of the c-kit protein product in carcinoma-in-situ and invasive testicular germ cell tumours. Int J Androl 17: 85-92.

RESNICK, J.L., BIXLER, L.S., CHENG, L. and DONOVAN, P.J. (1992). Long-term proliferation of mouse primordial germ cells in culture. Nature 359: 550-551.

RICHIARDI, L., BELLOCCO, R., ADAMI, H.O., TORRANG, A., BARLOW, L., HAKULINEN, T., RAHU, M., STENGREVICS, A., STORM, H., TRETLI, S. et al. (2004). Testicular cancer incidence in eight northern European countries: secular and recent trends. Cancer Epidemiol Biomarkers Prev 13: 2157-2166.

ROSKOSKI, R., JR. (2005). Signaling by Kit protein-tyrosine kinase--the stem cell factor receptor. Biochem Biophys Res Commun 337: 1-13.

SASAKI, A., TAKETOMI, T., KATO, R., SAEKI, K., NONAMI, A., SASAKI, M., KURIYAMA, M., SAITO, N., SHIBUYA, M. and YOSHIMURA, A. (2003). Mammalian Sprouty4 suppresses Ras-independent ERK activation by binding to Raf1. Cell Cycle 2: 281-282.

SATGE, D., JACOBSEN, G.K., CESSOT, F., RAFFI, F. and VEKEMANS, M. (1996) A fetus with Down syndrome and intratubular germ cell neoplasia. Pediatr Pathol Lab Med 16: 107-112.

SCHIER, A.F. (2009). Nodal morphogens. Cold Spring Harb Perspect Biol1: a003459

SCHIER, A.F. and SHEN, M.M. (2000). Nodal signalling in vertebrate development. Nature 403: 385-389.

SCHRADER, M., BURGER, A.M., MULLER, M., KRAUSE, H., STRAUB, B., SMITH G.L., NEWLANDS, E.S. and MILLER, K. (2002). Quantification of human telomerase reverse transcriptase mRNA in testicular germ cell tumors by quantitative fluorescence real-time RT-PCR. Oncol Rep 9: 1097-1105. 
SHAH, M.N., DEVESA, S.S., ZHU, K. and MCGLYNN, K.A. (2007). Trends in testicular germ cell tumours by ethnic group in the United States. Int $J$ Androl 30: 206-213; discussion 213-204.

SHEN, M.M. (2007). Nodal signaling: developmental roles and regulation. Development 134: 1023-1034.

SIGG, C. and HEDINGER, C. (1984). Atypical germ cells of the testis. Comparative ultrastructural and immunohistochemical investigations. Virchows Arch A Pathol Anat Histopathol 402: 439-450.

SKAKKEBAEK, N.E. (1972). Possible carcinoma-in-situ of the testis. Lancet2:516-517.

SKAKKEBAEK, N.E., BERTHELSEN, J.G., GIWERCMAN, A. and MULLER, J. (1987). Carcinoma-in-situ of the testis: possible origin from gonocytes and precursor of all types of germ cell tumours except spermatocytoma. Int $J$ Androl 10: 19-28.

SMITH, C.A., MCCLIVE, P.J., WESTERN, P.S., REED, K.J. and SINCLAIR, A.H. (1999). Conservation of a sex-determining gene. Nature 402: 601-602.

SONNE, S.B., ALMSTRUP, K., DALGAARD, M., JUNCKER, A.S., EDSGARD, D., RUBAN, L., HARRISON, N.J., SCHWAGER, C., ABDOLLAHI, A., HUBER, P.E. et al. (2009). Analysis of gene expression profiles of microdissected cell populations indicates that testicular carcinoma in situ is an arrested gonocyte. Cancer Res 69: 5241-5250.

SOUQUET, B., TOURPIN, S., MESSIAEN, S., MOISON, D., HABERT, R. and LIVERA, G. (2012). Nodal Signaling Regulates the Entry into Meiosis in Fetal Germ Cells. Endocrinology 153(5):2466-2473.

SPILLER, C.M., FENG, C.W., JACKSON, A., GILLIS, A.J.M., ROLLAND, A.D., LOOIJENGA, L.H.J., KOOPMAN, P. and BOWLES, J. (2012). Endogenous Nodal signaling regulates germ cell potency during mammalian testis development. Development 139(22):4123-4132.

STEVENS, L.C. (1967). Origin of testicular teratomas from primordial germ cells in mice. J Natl Cancer Inst 38: 549-552.

STEVENS, L.C. (1984). Spontaneous and experimentally induced testicular teratomas in mice. Cell Differ 15: 69-74.

SWERDLOW, A.J., DOS SANTOS SILVA, I., REID, A., QIAO, Z., BREWSTER, D.H. and ARRUNDALE, J. (1998). Trends in cancer incidence and mortality in Scotland: description and possible explanations. Br J Cancer 77 Suppl 3: 1-54.

TESAR, P.J., CHENOWETH, J.G., BROOK, F.A., DAVIES, T.J., EVANS, E.P., MACK, D.L., GARDNER, R.L. and MCKAY, R.D. (2007). New cell lines from mouse epiblast share defining features with human embryonic stem cells. Nature 448: 196-199.
TURNBULL, C. and RAHMAN, N. (2011). Genome-wide association studies provide new insights into the genetic basis of testicular germ-cell tumour. Int J Androl34: e86-96; discussion e96-87.

ULBRIGHT, T.M. (1999). Testis risk and prognostic factors. The pathologist's perspective. Urol Clin North Am 26: 611-626.

VALLIER, L., REYNOLDS, D. and PEDERSEN, R.A. (2004). Nodal inhibits differentiation of human embryonic stem cells along the neuroectodermal default pathway. Dev Biol 275: 403-421

VAN DE GEIJN, G.J., HERSMUS, R. and LOOIJENGA, L.H. (2009). Recent developments in testicular germ cell tumor research. Birth Defects Res $C$ Embryo Today 87: 96-113.

VISFELDT, J., JORGENSEN, N., MULLER, J., MOLLER, H. and SKAKKEBAEK, N.E. (1994). Testicular germ cell tumours of childhood in Denmark, 1943-1989: incidence and evaluation of histology using immunohistochemical techniques. $J$ Pathol 174: 39-47.

VON DER MAASE, H., RORTH, M., WALBOM-JORGENSEN, S., SORENSEN, B.L., CHRISTOPHERSEN, I.S., HALD, T., JACOBSEN, G.K., BERTHELSEN, J.G. and SKAKKEBAEK, N.E. (1986). Carcinoma in situ of contralateral testis in patients with testicular germ cell cancer: study of 27 cases in 500 patients. Br Med J (Clin Res Ed) 293: 1398-1401.

WATANABE, K., MEYER, M.J., STRIZZI, L., LEE, J.M., GONZALES, M., BIANCO, C., NAGAOKA, T., FARID, S.S., MARGARYAN, N., HENDRIX, M.J. et al. (2010). Cripto- 1 is a cell surface marker for a tumorigenic, undifferentiated subpopulation in human embryonal carcinoma cells. Stem Cells 28: 1303-1314.

WECHSELBERGER, C., STRIZZI, L., KENNEY, N., HIROTA, M., SUN, Y., EBERT, A., OROZCO, O., BIANCO, C., KHAN, N.I., WALLACE-JONES, B. et al. (2005). Human Cripto-1 overexpression in the mouse mammary gland results in the development of hyperplasia and adenocarcinoma. Oncogene 24: 4094-4105.

YAN, W., SAMSON, M., JEGOU, B. and TOPPARI, J. (2000). Bcl-w forms complexes with $\mathrm{Bax}$ and $\mathrm{Bak}$, and elevated ratios of $\mathrm{Bax} / \mathrm{Bcl}-\mathrm{w}$ and $\mathrm{Bak} / \mathrm{Bcl}-\mathrm{w}$ correspond to spermatogonial and spermatocyte apoptosis in the testis. Mol Endocrinol 14: 682-699.

YOUNGREN, K.K., COVENEY, D., PENG, X., BHATTACHARYA, C., SCHMIDT, L.S., NICKERSON, M.L., LAMB, B.T., DENG, J.M., BEHRINGER, R.R., CAPEL, B. et al. (2005). The Ter mutation in the dead end gene causes germ cell loss and testicular germ cell tumours. Nature 435: 360-364.s 


\section{Further Related Reading, published previously in the Int. J. Dev. Biol.}

Analysis of SOX2 expression in developing human testis and germ cell neoplasia Si B. Sonne, Rebecca M. Perrett, John E. Nielsen, Melissa A. Baxter, David M. Kristensen, Henrik Leffers, Neil A. Hanley and Ewa Rajpert-De-Meyts Int. J. Dev. Biol. (2010) 54: 755-760

Bone morphogenetic proteins (BMPs) induce epithelial differentiation of NT2D1 human embryonal carcinoma cells

ACaricasole, D Ward-van Oostwaard, LZeinstra, Avan den Eijnden-van Raaij and C Mummery Int. J. Dev. Biol. (2000) 44: 443-450

Differentiation of mouse primordial germ cells into female or male germ cells N Nakatsuji and S Chuma

Int. J. Dev. Biol. (2001) 45: 541-548

The meiotic specific synaptonemal complex protein SCP3 is expressed by female and male primordial germ cells of the mouse embryo

A D Di Carlo, G Travia and M De Felici

Int. J. Dev. Biol. (2000) 44: 241-244

The germ cell--the mother of all stem cells

P J Donovan

Int. J. Dev. Biol. (1998) 42: 1043-1050

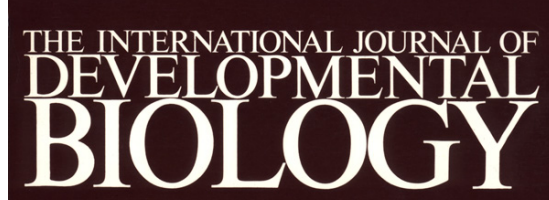

\section{Volume 37 No.1}

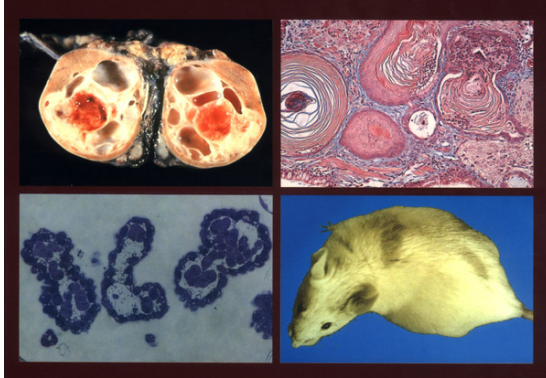

Developmental Aspects of Neoplasia
5 yr ISI Impact Factor $(2011)=2.959$

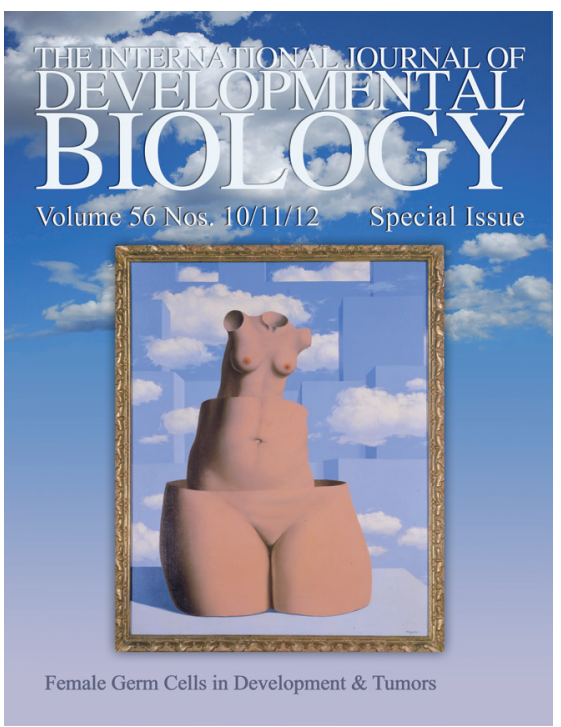

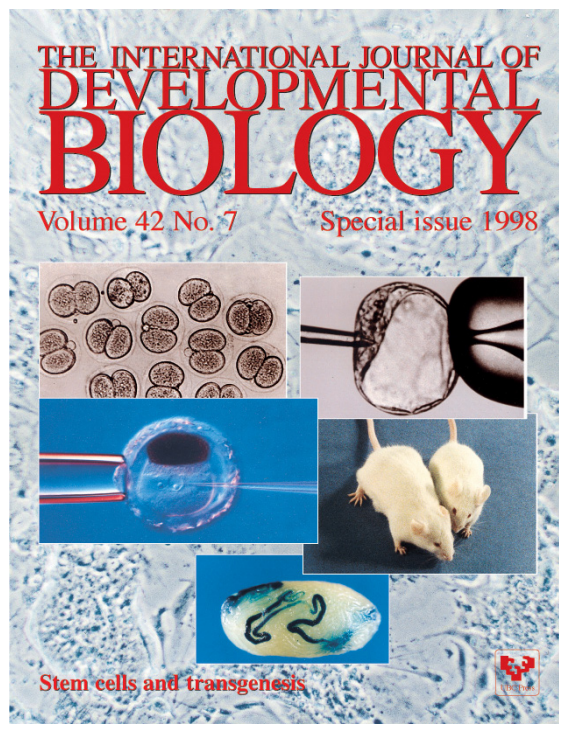
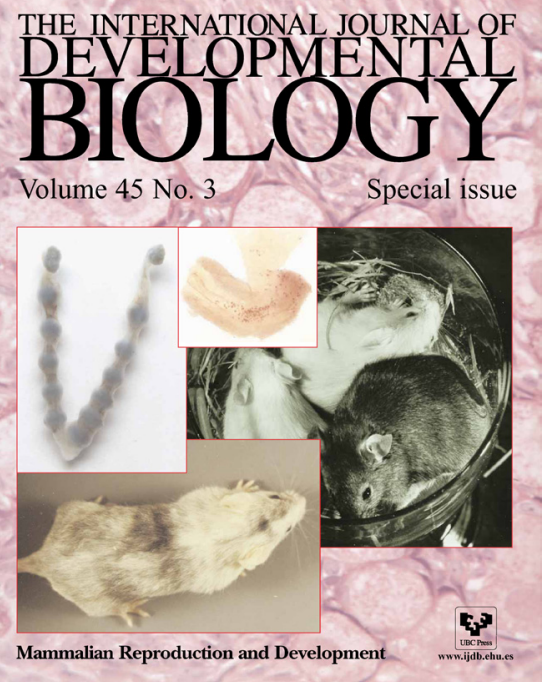